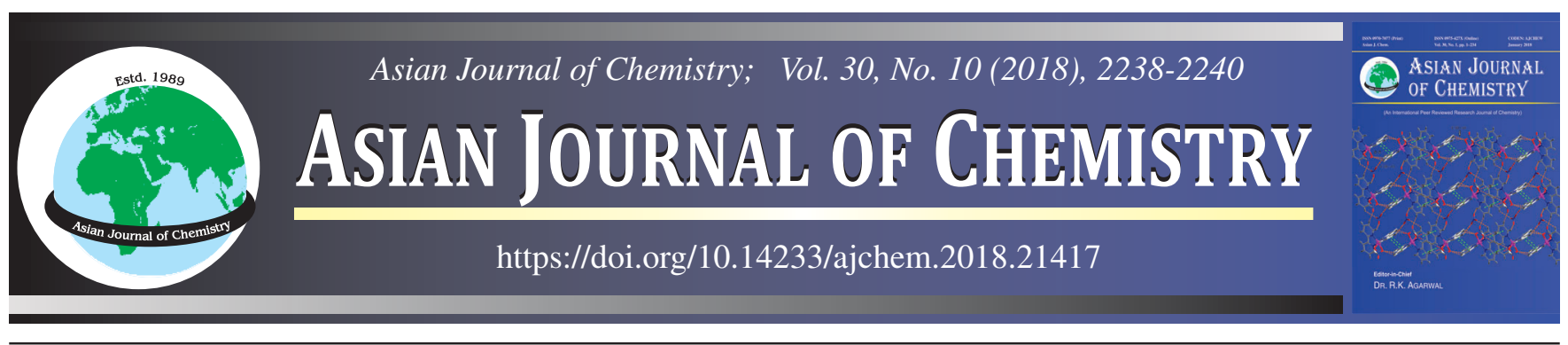

\title{
Synthesis, Characterization and Pharmacological Activity of Phenoxy Acetic Acid and Pyrazinium Chlorochromate
}

\begin{abstract}
K. Anbarasu and K.K. Ilavenil*
Department of Chemistry, Arignar Anna Government Arts College, Musiri-621 211, India

*Corresponding author: E-mail: illavenil81@gmail.com

This study describes the synthesis and antibacterial, antifungal activity of phenoxy acetic acid and pyrazinium chlorochromate. The compounds were characterized by infrared and ultra violet visible spectral data. These compounds were reviewed for antibacterial and antifungal activity against Streptococcus, Entrococcus, Bacillus cereus, Proteus vulgaris, Mycobacterium tuberculosis, Azotobacter, E. coli, Pseudomonas aeruginosa, Candida albicans, A. niger, Fusarium and Trichoderma by disc diffusion method.

Keywords: Phenoxy acetic acid, Pyrazinium chlorochromate, Biological activities.
\end{abstract}

ᄂ - - - - - - - - - - - - - - -

\section{INTRODUCTION}

The basic molecular structures of the heterocyclic system exhibit a broad range of biological and pharmacological activites [1] . Many new drugs are synthesized using these moeities. The over practice of antimicrobial drugs have produced more impedance to the bacterias and fugi. As a result many infectious diseases have come to light. In order to prevent the spreading of these diseases, the pharmacisit are in the need to develop a unique, wide-ranging of antimicrobial agents [2-4]. The heterocyclic ring consisting of nitrogen or sulphur atoms are researched for their physiochemical properties. The sensitivity of these heterocyclic compounds towards the biological properties plays a key role in the kinetic study [5,6].

The literature survey reveals that the pyrazine derivatives displays numerous properties like antibacterial [7], antiinflammatory [8], analgesic [9], ulcerogenic potential [10], antituberclosis [11], antimicrobial [12], antifungal, antioxidant, anticonvulsants [13], antiproliferative assay [14], serotonin activity [15], cytotoxic properties [16,17], antilipolytic activity [18], antidiabetic and antihistamines [19]. Several phenoxy derivatives illustrate antimycobacterial [20], antiviral [21], antituberclosis activity [22], hypolipidemic activity [23], antinociceptive [24], anti-inflammatory activity, antifungal activities [25], antioxidant activity [27], antidiabetic property [28].
Aspergillus niger and Fusarium species are plant pathogens and they affect the plant growth. The mycotoxins [29] produced by these are proned to cause lung defilement, ear infections and has been disclosed in HIV patients [30]. Phenoxy acetic acid, pyrazinium chlorochromate compounds are screened for their biological activites towards few Gram-positive, Gramnegative bacterias and fungi.

\section{EXPERIMENTAL}

AnalaR grade reagents are used for the synthesis of phenoxy acetic acid and pyrazinium chlorochromate. The melting points of these two compounds were determined by Thomas Hoover capillary melting point instrument. The IR spectra were recorded on FTIR Bruker Alpha and UV-visible spectra were reported using PerkinElmer Lamda 365 make instrument.

Synthesis of pyrazinium chlorochromate $\left(\mathrm{C}_{4} \mathrm{~N}_{2} \mathrm{H}_{5} \mathrm{CrO}_{3} \mathrm{Cl}\right)$ : An orange coloured solid was prepared by adding $1.30 \mathrm{mmol}$ of chromium trioxide and $2.4 \mathrm{mmol}$ of $12 \mathrm{M} \mathrm{HCl}$ in $2 \mathrm{~mL}$ of doubly distilled water with constant stirring to a solution of $2.24 \mathrm{mmol}$ of pyrazine and $2.28 \mathrm{mmol}$ of $12 \mathrm{M} \mathrm{HCl}$ in $4 \mathrm{~mL}$ of water, in ice bath. After constant stirring for $2 \mathrm{~h}$ at $0{ }^{\circ} \mathrm{C}$ an orange coloured solid [31] obtained was filtered and then dried. The recrystallized solid (Scheme-I) from acidifed water was used throughout the work (m.p. 148 to $150{ }^{\circ} \mathrm{C}$ ).

Preparation of phenoxy acetic acid $\left(\mathrm{C}_{8} \mathbf{H}_{8} \mathbf{O}_{3}\right)$ : To 11.47 mmol of sodium hydroxide $5 \mathrm{mmol}$ of phenol was added and

This is an open access journal, and articles are distributed under the terms of the Creative Commons Attribution-NonCommercial 4.0 International (CC BY-NC 4.0) License, which allows others to copy and redistribute the material in any medium or format, remix, transform, and build upon the material, as long as appropriate credit is given and the new creations are licensed under the identical terms. 


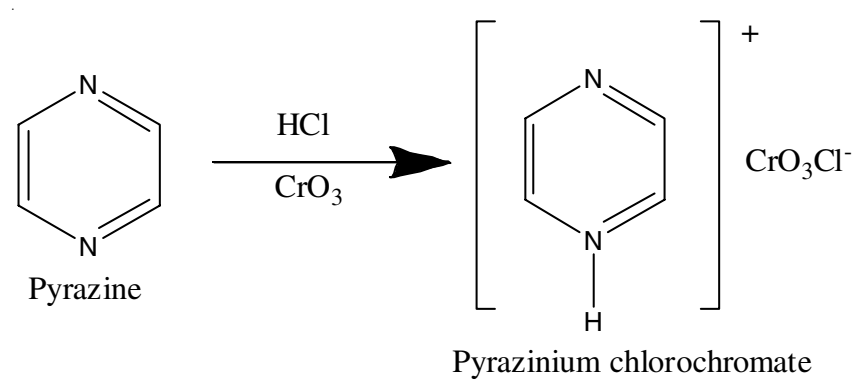

Scheme-I: Synthesis of pyrazinium chlorochromate (PzCC)

diluted. $6 \mathrm{mmol}$ of chloroacetic acid was dissolved in warm water and added to the above mixture and stirred constantly for $2 \mathrm{~h}$ at 60 to $80^{\circ} \mathrm{C} .35 \%$ Hydrochloric acid was added and vacum fractionated using benzene as solvent. The white coloured solid obtained (Scheme-II) was recrystallized using water and ethanol mixture (m.p. 98.2 to $98.9^{\circ} \mathrm{C}$ ) [32].

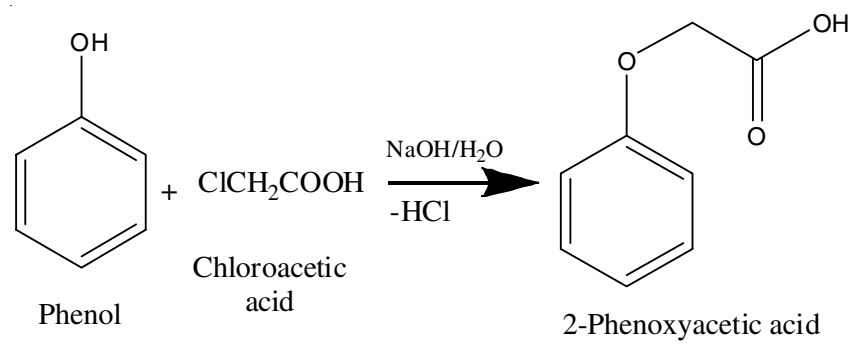

Scheme-II: Synthesis of phenoxy acetic acid

Phenoxy acetic acid: m.f. $\mathrm{C}_{8} \mathrm{H}_{8} \mathrm{O}_{3}$, m.p. $98.2-99.0{ }^{\circ} \mathrm{C}$, m.w. 152.15, Yield 98.5 \%. IR (KBr, $\left.v_{\max }, \mathrm{cm}^{1}\right) 3300,2467.70$, 859.16, 3000, 1441.72, 3120, 1607.11, 1172.25, 1348.95, 1235.27 1043.36. The UV-visible spectrum showed absorbance peaks at $216.85 \mathrm{~nm}(\mathrm{~s}), 268.70 \mathrm{~nm}(\mathrm{w})$, transmittance peaks at $216.85 \mathrm{~nm}(\mathrm{~s}), 268.70 \mathrm{~nm}(\mathrm{~s})$.

Pyrazinium chlorochromate: m.f. $\mathrm{C}_{4} \mathrm{~N}_{2} \mathrm{H}_{5} \mathrm{CrO}_{3} \mathrm{Cl}$, m.p. $148-154^{\circ} \mathrm{C}$, Yield 61\%. IR (KBr, $\left.v_{\max }, \mathrm{cm}^{-1}\right), 3113,3049,2955$, 2768, 2700, 2085, 1614, 1490, 1373, 608, 1160, 770. The UV-visible spectrum showed peaks at $312 \mathrm{~nm}(\mathrm{~m}, \mathrm{~b}), 267 \mathrm{~nm}$ (s), transmittance peaks at $260.05 \mathrm{~nm}$ (s), $350.45 \mathrm{~nm}$ (b), $772.80 \mathrm{~nm}(\mathrm{w})$.

Determination of biological potential: The solution of the phenoxy acetic acid and pyrazinium chlorochromate were prepared in various concentrations like $25,50,75$ and $100 \mu \mathrm{L}$ by dissolving in dimethy sulphoxide solvent.

Disc diffusion antibiotic sensitivity testing: The synthesized compounds were screened for antibacterial activity against Streptococcus, Entrococcus, Bacillus cereus, Proteus vulgaris, Mycobacterium tuberculosis, Azotobacter, E. coli, Pseudomonas aeruginosa, Candida albicans, A. niger, Fusarium and Trichoderma using the agar disc diffusion method [33-36].

Bacterial inoculums containing approximately $10^{5}-10^{6}$ colony forming units $(\mathrm{CFU}) / \mathrm{mL}$ were used at $37^{\circ} \mathrm{C}$. The culture medium (Agar medium) was composed of peptone $5 \mathrm{~g} / \mathrm{L}$, NaCl-5 g/L, Agar-15 g/L, Beef extract-3 g/L, Yeast extract$1.5 \mathrm{~g} / \mathrm{L}$. The $\mathrm{pH}$ was maintained to be neutral at 7. All the materials were diluted in doubly distilled water and the medium was sterilized at $121^{\circ} \mathrm{C}$ for $20 \mathrm{~min}$ at pressure $15 \mathrm{psi}$. The solutions of the chemical compounds were prepared at the concentration of $25,50,75$ and $100 \mu \mathrm{L}$ in DMSO.

The agar plate was incubated for 20 to $28 \mathrm{~h}$ at $37-38^{\circ} \mathrm{C}$ for bacteria and $25^{\circ} \mathrm{C}$ for fungi by following the standard procedure. Ciprofloxacin was selected as the standard and the zone of inhibition were measured and compared with the controls. Bacterial cultures were obtained from Eumic analytical Lab and Research Institute, Tiruchirappalli. Bacterial strains were maintained on Nutrient agar slants (Hi media) at $4{ }^{\circ} \mathrm{C}$.

\section{RESULTS AND DISCUSSION}

As the concentration of phenoxy acetic acid and pyrazinium chlorochromate increased from 25 to $100 \mu \mathrm{L}$. The lethal zone of the bacteria and fungi also increased (Tables 1 and 2). The inhibition for the organic compound phenoxy acetic acid was high at $100 \mu \mathrm{L}$ for (Gram-positive bacteria) Mycobacterium tuberclosis, Proteus vulgaris (Gram-negative bacteria) and fungi, Aspergillus niger, Fusarium and Trichoderma than the control of standard drug ciprofloxacin. Likewise for heterocyclic pyrazinium chlorochromate compound the impedance was more for (Gram-positive bacteria) Mycobacterium tuberclosis, (Gram-negative bacteria) Proteus vulgaris and fungi as discussed above.

\section{Conclusion}

At higher concentration $(100 \mu \mathrm{L})$ the phenoxy acetic acid exhibited good resistant towards the organisms like Bacillus

INHIBITION ZONE FOR PHENOXY ACETIC ACID

\begin{tabular}{|c|c|c|c|c|c|c|}
\hline \multirow{2}{*}{ Organisms } & \multirow{2}{*}{ Gram stain } & \multicolumn{5}{|c|}{ Control $100 \mu \mathrm{L}$ added and zone of inhibition $(\mathrm{mm} / \mathrm{mL})$} \\
\hline & & $25 \mu \mathrm{L}$ & $75 \mu \mathrm{L}$ & $50 \mu \mathrm{L}$ & $100 \mu \mathrm{L}$ & Control \\
\hline Streptococcus & Gram-positive bacteria & 10 & 12 & 14 & 16 & 30 \\
\hline Bacillus cereus & Gram-positive bacteria & 12 & 14 & 16 & 18 & 20 \\
\hline Entrococcus & Gram-positive bacteria & 10 & 12 & 14 & 16 & 20 \\
\hline Proteus vulgaris & Gram-negative bacteria & 10 & 12 & 14 & 16 & 15 \\
\hline Micrococcus & Gram-positive bacteria & 10 & 11 & 13 & 16 & 30 \\
\hline Mycobacterium tuberclosis & Gram-positive bacteria & 12 & 15 & 18 & 20 & 22 \\
\hline Azotobacter & Gram-negative bacteria & 12 & 14 & 16 & 18 & 25 \\
\hline E. coli & Gram-negative bacteria & 10 & 12 & 14 & 16 & 25 \\
\hline Pseudomonas aeruginosa & Gram-negative bacteria & 12 & 15 & 18 & 20 & 25 \\
\hline Candida albicans & Fungi & 12 & 14 & 16 & 19 & 32 \\
\hline A. niger & Fungi & - & 10 & 11 & 12 & 12 \\
\hline Fusarium & Fungi & 11 & 13 & 16 & 18 & 12 \\
\hline Trichoderma & Fungi & 10 & 11 & 12 & 14 & 12 \\
\hline
\end{tabular}


TABLE-2

INHIBITION ZONE FOR PYRAZINIUM CHLOROCHROMATE

\begin{tabular}{|c|c|c|c|c|c|c|}
\hline \multirow{2}{*}{ Organisms } & \multirow{2}{*}{ Gram stain } & \multicolumn{5}{|c|}{ Control $100 \mu \mathrm{L}$ added and zone of inhibition $(\mathrm{mm} / \mathrm{mL})$} \\
\hline & & $25 \mu \mathrm{L}$ & $75 \mu \mathrm{L}$ & $50 \mu \mathrm{L}$ & $100 \mu \mathrm{L}$ & Control \\
\hline Streptococcus & Gram-positive bacteria & 10 & 12 & 14 & 16 & 28 \\
\hline Bacillus cereus & Gram-positive bacteria & 12 & 14 & 16 & 18 & 22 \\
\hline Entrococcus & Gram-positive bacteria & 12 & 15 & 18 & 20 & 22 \\
\hline Proteus vulgaris & Gram-negative bacteria & 14 & 17 & 21 & 25 & 15 \\
\hline Micrococcus & Gram-positive bacteria & - & 10 & 11 & 12 & 20 \\
\hline Mycobacterium tuberclosis & Gram-positive bacteria & 14 & 16 & 18 & 20 & 20 \\
\hline Azotobacter & Gram-negative bacteria & 10 & 12 & 14 & 16 & 25 \\
\hline E. coli & Gram-negative bacteria & 12 & 14 & 16 & 18 & 25 \\
\hline Pseudomonas aeruginosa & Gram-negative bacteria & 10 & 11 & 13 & 15 & 23 \\
\hline Candida albicans & Fungi & 12 & 15 & 18 & 21 & 30 \\
\hline A. niger & Fungi & 10 & 11 & 12 & 14 & 12 \\
\hline Fusarium & Fungi & - & 10 & 11 & 12 & 12 \\
\hline Trichoderma & Fungi & 10 & 12 & 14 & 16 & 14 \\
\hline
\end{tabular}

cereus, Proteus vulgaris, Mycobacterium tuberclosis, Aspergiullus niger, Fusarium, Trichoderma and pyrazinium chlorochromate were resistant towards Entrococcus, Proteus vulgaris, Mycobacterium tuberclosis, Aspergiullus niger and Fusarium, Trichoderma.

\section{CONFLICT OF INTEREST}

The authors declare that there is no conflict of interests regarding the publication of this article.

\section{REFERENCES}

1. A.P. Taylor, R.P. Robinson, Y.M. Fobian, D.C. Blakemore, L.H. Jones and O. Fadeyi, Org. Biomol. Chem., 14, 6611 (2016); https://doi.org/10.1039/C6OB00936K.

2. R. Chawla, U. Sahoo, A. Arora, P.C. Sharma and V. Radhakrishnan, Acta Pol. Pharm. Drug Res., 67, 55 (2010).

3. A.R. Katritzky, Chem. Rev., 104, 2125 (2004); https://doi.org/10.1021/cr0406413.

4. M.E. Azab, M.M. Youssef and E.A. El-Bordany, Molecules, 18, 832 (2013); https://doi.org/10.3390/molecules 18010832 .

5. K.G. Sekar and G. Manikandan, Oxid. Commun., 35, 577 (2012).

6. B.H. Asghar, Arab. J. Chem.; https://doi.org/10.1016/j.arabjc. 2015.04.006.

7. H. Foks, D. Pancechowska-Ksepko, A. Kedzia, Z. Zwolska, M. Janowiec and E. Augustynowicz-Kopec, II Farmaco, 60, 513 (2005); https://doi.org/10.1016/i.farmac.2005.05.002.

8. E. Abignente, Actual Chim. Ther, 18, 193 (1991).

9. P. Gund and T.Y. Shen, J. Med. Chem., 20, 1146 (1977); https://doi.org/10.1021/jm00219a007.

10. E. Abignente, P. de Caprariis, M.G. Rimoli, L. Avallone, L. Gomez Paloma, F. Rossi, M. D'Amico, V. Calderaro and C. Parrillo, Eur. J. Med. Chem., 28, 337 (1993); https://doi.org/10.1016/0223-5234(93)90150-D.

11. M.V. Baldwin, D.A. Sonia, T.J. Sindhu, C. Meena, A.R. Bhar and K. Krishnakumar, World J. Pharm. Pharm. Sci., 3, 1124 (2014).

12. M. Gür, N. Sener, H. Muglu, M.S. Çavus, O.E. Özkan, F. Kandemirli and I. Sener, J. Mol. Struct., 1139, 111 (2017); https://doi.org/10.1016/j.molstruc.2017.03.019.

13. K. Nishie, A.C. Waiss Jr. and A.C. Keyl, Toxicol. Appl. Pharmacol., 17, 244 (1970); https://doi.org/10.1016/0041-008X(70)90149-3.

14. L. Racané, S. Kraljevic Pavelic, I. Ratkaj, V. Stepanic, K. Pavelic, V. TralicKulenovic and G. Karminski-Zamola, Eur. J. Med. Chem., 55, 108 (2012); https://doi.org/10.1016/j.ejmech.2012.07.005.

15. B.V. Clineschmidt, J.C. McGuffin and A.B. Pflueger, Eur. J. Pharmacol., 44, 65 (1977); https://doi.org/10.1016/0014-2999(77)90117-0.

16. N. Dias, U. Jacquemard, B. Baldeyrou, A. Lansiaux, J.-F. Goossens, C. Bailly, S. Routier and J.-Y. Mérour, Eur. J. Med. Chem., 40, 1206 (2005); https://doi.org/10.1016/j.ejmech.2005.07.003.
17. R.S. Kumar, I.A. Arif, A. Ahamed and A. Idhayadhulla, Saudi J. Biol. Sci., 23, 614 (2016); https://doi.org/10.1016/j.sibs.2015.07.005.

18. P.P. Lovisolo, G. Briatico-Vangosa, G. Orsini, R. Ronchi, R. Angelucci and G. Valzelli, Pharmacol. Res. Commun., 13, 151 (1981); https://doi.org/10.1016/S0031-6989(81)80016-1.

19. C.P. Meher, A.M. Rao and Md. Omar, Asian J. Pharm. Sci. Res., 3, 43 (2013).

20. M. Shahar Yar, A.A. Siddiqui and M.A. Ali, Bioorg. Med. Chem. Lett., 16, 4571 (2006) https://doi.org/10.1016/j.bmcl.2006.06.021.

21. M. Shahar Yar, M.A. Bakht, A.A. Siddiqui, M.M. Abdullah and E. De Clercq, J. Enzym. Inhib. Med. Chem., 24, 876 (2009); https://doi.org/10.1080/14756360802447917.

22. M.A. Ali, M.S. Yar, M. Kumar and G.S. Pandian, Nat. Prod. Res., 21, 575 (2007); https://doi.org/10.1080/14786410701369367.

23. S.N. Mokale, M.C. Nevase, N.S. Sakle, P.N. Dube, V.R. Shelke, S.A. Bhavale and A. Begum, Bioorg. Med. Chem. Lett., 24, 2155 (2014); https://doi.org/10.1016/j.bmcl.2014.03.030.

24. G. Turan-Zitouni, L. Yurttas, Z.A. Kaplancikli, Ö.D. Can and Ü. Demir Özkay, Med. Chem. Res., 24, 2406 (2015); https://doi.org/10.1007/s00044-014-1309-1.

25. A. Iqbal, H. Siddiqui, C. Ashraf, M. Ahmad and G. Weaver, Molecules, 12, 245 (2007); https://doi.org/10.3390/12020245.

26. M. Urban, J. Sarek, M. Kvasnica, I. Tislerova and M. Hajduch, J. Nat. Prod., 70, 526 (2007); https://doi.org/10.1021/np060436d.

27. M. Kucerova-Chlupacova, M. Dosedel, J. Kunes, M. Soltesova-Prnova, M. Majekova and M. Stefek, Monatsh. Chem., 149, 921 (2018); https://doi.org/10.1007/s00706-018-2146-6.

28. X. Wang, T. Zhao, B. Yang, Z. Li, J. Cui, Y. Dai, Q. Qiu, H. Qiang, W. Huang and H. Qian, Bioorg. Med. Chem. Lett., 23, 132 (2015); https://doi.org/10.1016/j.bmc.2014.11.016.

29. A. Ghafoor and S.A.J. Khan, List of Diseases of Econonomic Plants in Pakistan, Ministry of Food and Agriculture, Islamabad, Pakistan, pp. 26 (1976).

30. I. Rzewnicki, E. Olszewska and D. Rogowska-Szadkowska, Med. Sci. Monit., 18, RA17 (2012); https://doi.org/10.12659/MSM.882505.

31. G.L. Gard, H.B. Davis, R.M. Sheets, J.M. Brannfors and W.W. Paudler, Heterocycles, 20, 2029 (1983); https://doi.org/10.3987/R-1983-10-2029.

32. C.F. Koelsch, J. Am. Chem. Soc., 53, 304 (1931); https://doi.org/10.1021/ja01352a042.

33. Atta-ur-Rahman, M.I. Choudhary and W.J. Thomsen, Bioassay Techniques for Drug Dtwelopment, Harwood Academic Publishers, The Netherlands, p. 16 (2001)

34. K.M. Khan, Z.S. Saify, M.Z. Khan, Zia-Ullah, M.I. Choudhary, Attaur-Rahman, S. Perveen, Z.H. Chohan and C.T. Supuran, J. Enzym. Inhib. Med. Chem., 19, 373 (2004); https://doi.org/10.1080/14756360409162453. 